\title{
Life Cycle Cost and Sensitivity Analysis of Reutealis trisperma as Non-Edible Feedstock for Future Biodiesel Production
}

\author{
Teuku Meurah Indra Riayatsyah ${ }^{1}$, Hwai Chyuan Ong ${ }^{1, *}$, Wen Tong Chong ${ }^{1}$ (D), Lisa Aditya ${ }^{1}$, \\ Heri Hermansyah ${ }^{2}$ and Teuku Meurah Indra Mahlia ${ }^{3,4}$ \\ 1 Department of Mechanical Engineering, Faculty of Engineering, University of Malaya, \\ 50603 Kuala Lumpur, Malaysia; indraayat@gmail.com (T.M.I.R.); chong_wentong@um.edu.my (W.T.C.); \\ lisaadityamawardi@gmail.com (L.A.) \\ 2 Department of Chemical Engineering, Universitas Indonesia, Depok 16424, Indonesia; heri@eng.ui.ac.id \\ 3 Department of Mechanical Engineering, Universiti Tenaga Nasional, 43000 Kajang, Selangor, Malaysia; \\ indra@uniten.edu.my \\ 4 Faculty of Integrated Technologies, Universiti Brunei Darussalam, Jalan Tungku Link, \\ Gadong BE1410, Brunei Darussalam \\ * Correspondence: onghc@um.edu.my; Tel.: +60-16-590-3110
}

Received: 4 April 2017; Accepted: 22 June 2017; Published: 29 June 2017

\begin{abstract}
The use of non-edible, second-generation feedstocks for the production of biodiesel has been an active area of research, due to its potential in replacing fossil diesel as well as its environmentally friendly qualities. Despite this, more needs to be done to remove the technical barriers associated with biodiesel production and usage, to increase its quality as well as to widen the choice of available feedstocks; so as to avoid over-dependence on limited sources. This paper assesses the feasibility of using a local plant, Reutealis trisperma, whose seeds contain a high percentage of oil of up to $51 \%$, as one of the possible feedstocks. The techno-economic and sensitivity analysis of biodiesel production from Reutealis trisperma oil as well as implementation aspects and environmental effects of the biodiesel plant are discussed. Analysis indicates that the $50 \mathrm{kt}$ Reutealis trisperma biodiesel production plant has a life cycle cost of approximately $\$ 710$ million, yielding a payback period of 4.34 years. The unit cost of the biodiesel is calculated to be $\$ 0.69 / \mathrm{L}$ with the feedstock cost accounting for the bulk of the cost. The most important finding from this study is that the biodiesel from Reutealis trisperma oil can compete with fossil diesel, provided that appropriate policies of tax exemptions and subsidies can be put in place. To conclude, further studies on biodiesel production and its limitations are necessary before the use of biodiesel from Reutealis trisperma oil may be used as a fuel source to replace fossil diesel.
\end{abstract}

Keywords: biodiesel; non-edible oil; Reutealis trisperma; life cycle cost; biofuel economy

\section{Introduction}

The diminishing supply of fossil fuel reserves and increasing environmental problems associated with the burning of fossil fuel have made renewable energies very promising as future alternative energy sources [1-3]. Among the renewable energies, biodiesel has been touted as one of the most important renewable energy sources, especially in the context of Malaysia [4,5]. Biodiesel is defined as mono-alkyl esters derived from long chain fatty acids contained in animal fats and vegetable oils, and processed using alcohol and a catalyst. It is environmentally friendly, non-toxic, and of course, abundant in nature [6-8].

Reference [9] focuses on the engine performance of biodiesel when used in diesel engines. The research reveals that fuels from biodiesel, made through transesterification of waste vegetable 
oil, may be used without significant impacts on the performance of direct injection (DI) and indirect injection (IDI) diesel engines. In reference [10], the authors conducted experiments to investigate the benefits of mixing biodiesels with petrol diesel fuel, with one-cylinder diesel engines using a wide range of biodiesel blends from linseed oil and conclusive results were obtained showing that a mixture of B20 (Biodiesel 20\%) produces the optimum thermal efficiency and emissions for the engine. In other studies, it has been shown that $10 \%$ biodiesel blends of non-edible oils; Jatropha curcas, Ceiba pentandra, and Calophyllum inophyllum, provides the best engine performance in terms of thermal efficiency, engine power, engine torque, and fuel consumption of a Compression Ignition (CI) engine [11]. These studies serve to demonstrate the huge potential of biodiesel to supplement or even replace fossil diesel fuel, without requiring engine modifications and without experiencing deterioration in engine performance. Furthermore, the use of biodiesel can extend the life of the diesel engine; due to its better lubricating properties as compared to petrol diesel [12].

There are different types of feedstocks; from animal fats, vegetable oils, and algae, that may be used to produce environmentally friendly biodiesel. First generation feedstocks, produced directly from food crops and edible vegetable oils, such as rapeseed and soybean oils are the most commonly used raw materials for the production of biodiesel. However, the use of first generation feedstock has somehow been given negative publicity recently and has attracted the attention of researchers due to the issue of "food versus fuel". As first generation feedstocks are essentially food crops, its use for the production of biodiesel has driven away a large chunk of food crops from the global food consumption market; causing an inevitable increase in its price.

Hence, a number of researchers have turned their attention to second generation feedstocks. These second generation feedstocks are generally produced from non-edible food crops or non-edible vegetable oils such as wood, waste, etc., in order to avoid the conflict associated with the first generation feedstocks. Included in the second generation feedstocks is waste or used cooking oil [13-15]. Numerous works have reported the potential of non-edible vegetable oils due to its physicochemical properties, its environmentally friendliness, and availability; allowing the production of biodiesel in a sustainable manner.

In addition, recent studies also present third generation feedstocks, taking advantage of specifically engineered energy crops such as microalgae for biodiesel production. References [16-18] have reported the economic advantages of using microalgae as feedstocks, in terms of the minimal land required as well as higher oil extraction capability of microalgae as compared to other feedstocks. Microalgae can also be grown on land and water unsuitable for food agriculture; reducing the strain on fertile lands and our already-depleted water sources. Because of these, third generation feedstocks have huge potential to be the future source of feedstocks for the production of biodiesel.

The production of biodiesel from feedstocks may be achieved using different techniques such as direct/blends [19,20], micro-emulsion [21], pyrolysis [22,23], and transesterification [24,25]; with the transesterification reaction with a catalytic process being the most commonly adopted technique for production [26]. Commonly, homogeneous catalysts such as Sodium Hydroxide ( $\mathrm{NaOH})$ and Potassium Hydroxide $(\mathrm{KOH})$ are used. Recently, the use of new heterogeneous catalysts in transesterification processes has become an interesting option for researchers. References [27-33] address the use of different heterogeneous catalysts for the production of biodiesel using different feedstocks. The authors in reference [30] investigated biodiesel production from Jatropha oil using nanometer magnetic base catalysts and have shown that a 95-99\% biodiesel yield is achievable under optimal conditions. These studies have demonstrated that the use of heterogeneous catalysts has reduced the effects of using low quality feedstocks, whilst providing high biodiesel yields under optimal conditions. Another interesting technique for biodiesel production is through catalyst-free techniques as demonstrated in references [34,35]; with a maximum biodiesel yield of $99.6 \%$ obtained in reference [35] for biodiesel production from Jatropha oil. Despite all these advancements, the determining factor in the choice of catalysts to be used in biodiesel production still hinges on the 
economic viability of the resulting biodiesel fuel; and hence, the current popularity of $\mathrm{NaOH}$ and $\mathrm{KOH}$ due to its relatively cheap price.

It is believed that the production of biodiesel should not rely on one source of feedstocks and the use of a single catalyst only. By taking lessons from our past dependency on fossil fuels, the over reliance on a single feedstock or catalyst will result in the fundamental economic problem of resource scarcity, especially in the long term. As such, the research communities continue to explore new possible source of feedstocks and catalysts for biodiesel production; the more varieties of feedstocks that are available and tested, the more assured is biodiesel in terms of sustainability and feasibility. Several examples of research efforts on crops for the production of biodiesel are calophyllum inophyllum [36], pongamia glabra (koroch seed) [37], jatropha curcas [38,39], eruca sativa. L [40], Hevea brasiliensis and Ricinus communis [41] pongamia pinnata (karanja) [42,43], sterculia foetida [44], azadirachta indica (neem) [45], madhuca indica (mahua) [46], soap nut [47,48], milkweed (Calotropis gigantean) [49], guizotia abyssinica [50], tung [51], pistacia chinensis [52], and algae [18].

This paper attempts to expand the body of knowledge on possible feedstocks for the production of biodiesel. It is noted that there is very little information available in the literature on the production of biodiesel from Reutealis trisperma [53]; despite its abundance in the Southeast Asian region. Therefore, the objective of the present paper is to examine the opportunity of biodiesel production from Reutealis trisperma oil as a potential source of future energy supply and to explore its implementation aspects. These are important in the context of Southeast Asia as feedstocks for biodiesel usually depends on the availability of that feedstock in its geographical region [54].

\section{Material and Methods}

\subsection{Materials}

Reutealis trisperma, also known as Philippine tung, is a monotypic plant genus in the Euphorbiaceae family [55]. It is a tall tree native to the Philippines and Southeast Asia; however, it has also been cultivated elsewhere due to its suitability as a timber species. For the same reason, the tree has also been classified by the International Union for Conservation of Nature and Natural Resources (IUCN) as being "Vulnerable" [56]. Figure 1 shows the distribution map of the Reutealis trisperma plant around the world.

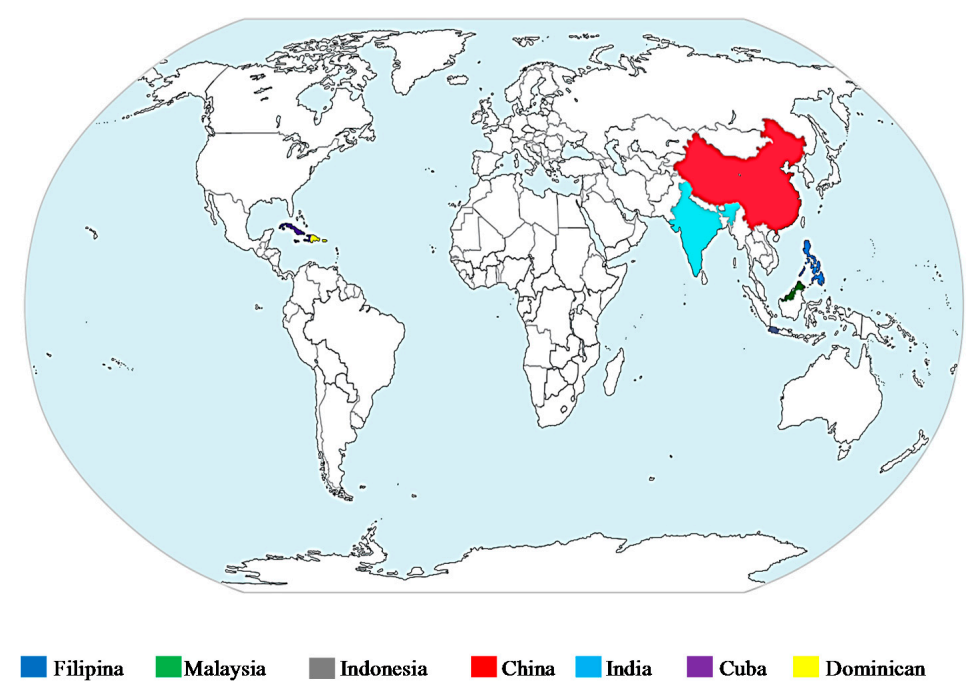

Figure 1. Distribution map of the Reutealis trisperma plant around the world.

Reutealis trisperma has the right characteristics for environmental rehabilitation plants; it is able to prevent land erosion and is an excellent producer of oxygen to the environment. It has been suggested 
in reference [57] that the tree be planted as part of plantations, in part to support the land rehabilitation program in Indonesia. The tree produces plenty of non-edible fruits, containing seeds and shells. Figure 2 depicts the tree, fruit, seeds, and kernels of the Reutealis trisperma plant. The seeds of this plant contain a high percentage of oil, up to $56 \%$ oil content [58]; consisting of palmitic acid, stearic acid, oleic acid, linoleic acid, and $\alpha$-eaeostrearic acid, and can be used as an environmentally friendly alternative fuel. Due to the presence of $\alpha$-eaeostrearic acid, the seed oil is non-edible and hence, the feedstock is classified as a second generation feedstock. Furthermore, the waste from processing can be used as natural pesticides and organic fertilizers [53,57]. Thus the growing of Reutealis trisperma serves several purposes; as a tool for land rehabilitation, for processing of its seed into biodiesel, and for the production of natural pesticides and organic fertilizers.

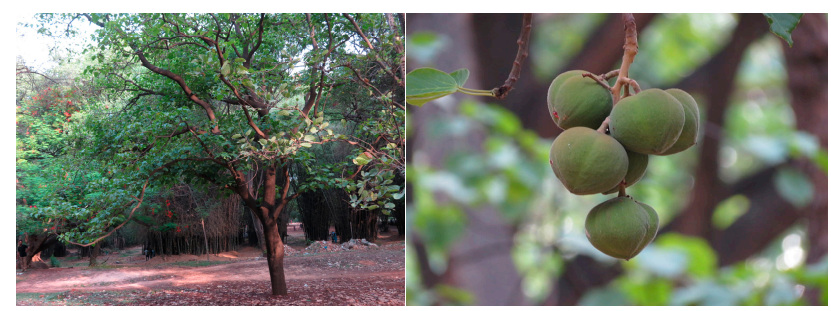

(a)

(b)

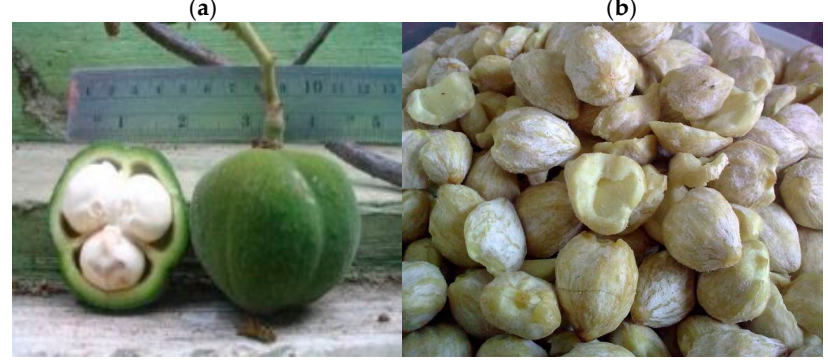

(c)

(d)

Figure 2. Reutealis trisperma: (a) Tree; (b) Fruits; (c) seeds; and (d) Kernels.

Before even considering the use of Reutealis trisperma as a source of feedstock for a biodiesel plant, it is important to first assess the suitability of the feedstocks in terms of physicochemical properties, to ensure that it is in agreement with biodiesel standard limits, particularly the ASTM D6751 and EN 14214 biodiesel standards. Laboratory experiments shall be performed to measure the physicochemical properties such as calorific value, density, etc., and these values shall be compared with the standards, to ensure compliance to the standards. Furthermore, the values obtained from this experiment shall also be used in subsequent sections in this paper.

\subsection{Method}

\subsubsection{Data Collection}

Data are collected from various sources such as research papers, technical notes, and reports from subject-matter experts as well as from the latest market prices, in addition to the data from experimental results. Where no specific data on the matter is available, assumptions shall be made using comparable data. Furthermore, sensitivity analysis shall be performed to identify the most important data as well as the effects of variations from the true values.

Generally, the basis of study on the biodiesel production plant shall be based on the production capacity of the plant. A common production capacity value of $50 \mathrm{kt}$ shall be assumed.

\subsubsection{Life Cycle Cost}

Life cycle costs of the plant may be used to evaluate the economic benefits of the plant. Sometimes referred to in the literature as total ownership cost, the life cycle cost must consider all costs associated 
with the plant; from its inception to decommissioning. For our purpose, the life cycle costs of the plant for the production of biodiesel oil from Reutealis trisperma may be divided into six (6) parameters; initial capital cost, operating cost, maintenance cost, feedstock costs, salvage value, and by-product credits, and are related as follow:

$$
L C C=C C+O C+M C+F C-S V-B P
$$

Recently, present value calculation is widely used in the economics and business to compare cast flows at different times. By applying the given approach, the present value model for the life cycle cost is presented as follows:

$$
L C C=C C+\sum_{i=1}^{n} \frac{O C_{i}+M C_{i}+F C_{i}}{(1+r)^{i}}-\frac{S V}{(1+r)^{n}}-\sum_{i=1}^{n} \frac{B P_{i}}{(1+r)^{i}}
$$

\section{Present Worth Factor}

The present value factor $(P W F)$ is the total estimated value of the project that is currently collected from future cash flows. The feasibility of investing in a biodiesel production plant is determined by using the present worth factors $(P W F)$ with a given rate of interest. For years $i, P W F$ is given as follows:

$$
P W F=\frac{1}{(1+r)^{i}}
$$

Summing this over a project period of $n$ years yields the compound present worth factor $(C P W)$,

$$
\begin{gathered}
C P W=\sum_{i=1}^{n} \frac{1}{(1+r)^{i}} \\
C P W=\frac{(1+r)^{n}-1}{r(1+r)^{n}}
\end{gathered}
$$

\section{Capital Cost}

Capital cost of the plant includes the initial costs for installation of the plant to allow for its operation; from the cost of the land, building cost, equipment, testing etc. Normally, capital cost is dependent on the production capacity of the plant. For this paper, capital cost is approximated based on reference [59], whereby three (3) possible initial capital costs may be considered based on the production capacity of the plant; maximum $C C_{h i g h}$, average $C C_{\text {avg }}$, and minimum $C C_{\text {low }}$ initial capital costs of the biofuel plant. These 3 possible initial capital costs of the biofuel production plant are given as follow:

$$
\begin{aligned}
& C C_{\text {high }}=-517.76 \times P C^{2}+252928 \times P C+3446300 \\
& C C_{\text {avg }}=-430.13 \times P C^{2}+205235 \times P C+2696000 \\
& C C_{\text {low }}=-342.49 \times P C^{2}+157542 \times P C+1945700
\end{aligned}
$$

\section{Operating Cost}

The operating cost include factory costs, transportation costs, utilities costs, administrative expenses, laboratory services, supervision costs, labor costs, and all other material and energy flows excluding the cost of the feedstocks. Costs for waste and sewage sludge treatments are also included in the operating cost. The operating cost consists of fixed and variable operating costs and by assuming that the plant is producing biodiesel at its maximum production capacity, the operating cost per ton of biodiesel produced may be introduced. 
Furthermore, assuming that the operating cost per ton of the plant are fixed throughout its project lifetime, the total operating costs $(O C)$ throughout the project lifetime, using present value calculations, may be given as follows:

$$
O C=\sum_{i=1}^{n} \frac{O R \times P C}{(1+r)^{i}}
$$

\section{Maintenance Cost}

Service and periodic maintenance costs may be taken to be a given percentage (MR) of the initial capital cost $(C C)$ and assumed to be constant for the whole project life span. The total maintenance costs $(M C)$ throughout the project lifetime, using present value calculations, may be given as follows:

$$
M C=\sum_{i=1}^{n} \frac{M R \times C C}{(1+r)^{i}}
$$

\section{Feedstock Cost}

Annual feedstock consumption $(F U)$ of the plant is determined by the capacity of the plant $(P C)$; after accounting for the biodiesel conversion efficiency $(C E)$ which is the efficiency in which the feedstock is converted into biodiesel. Further, it is assumed that annual feedstock consumption $(F U)$ is constant throughout the project lifetime and is given by:

$$
F U=\frac{P C}{C E}
$$

The total feedstock costs $(F C)$ throughout the project lifetime, using present value calculations may be given as follows:

$$
F C=\sum_{i=1}^{n} \frac{F P \times F U}{(1+r)^{i}}
$$

Salvage Value

The salvage value is the remaining value of components and assets of the project at the end of its lifetime; however, instead of using the initial capital cost as the basis for the calculation, the cost of replacing the plant and its assets i.e., the replacement $\operatorname{cost}(R C)$, is used. This is because intuitively the salvage value of the plant at the end of its lifetime is determined by the capital cost at the end of the project lifetime, after discounting for depreciations. A constant annual depreciation rate $(d)$ is assumed in this study. The salvage value, using present value calculations, may be estimated by the following equation:

$$
S V=R C \times(1-d)^{n-1}
$$

Therefore, the current value of the salvage cost is expressed by the following equation:

$$
S V_{P V}=\sum_{i=1}^{n} \frac{R C \times(1-d)^{n-1}}{(1+r)^{n}}
$$

\section{By-Product Credits}

Glycerol is a by-product of the biodiesel production process. Although unusable for biodiesel use, it may be further converted into different products such as Fuel Oxygenates (additive), propylene glycol (liquid alcohol that is used as a solvent, in antifreeze, and in the food, plastics, and perfume industries), Reforming Syngas, Glycerol Carbonate, etc. The authors in [60] state that glycerol can be converted and used as a solvent, antifreeze, in pharmaceutical applications, and numerous other products through catalytic conversion. As such, Glycerol may actually be sold further as a useful by-product. 
Of course, the receivables from the sale of Glycerol, as a by-product of the plant, is determined by the actual amount of Glycerol that is produced. Given a glycerol conversion factor of GCF, the by-product credit obtained from the sale of Glycerol over the project lifetime, using present value calculations, may be given as:

$$
B P=\sum_{i=1}^{n} \frac{G P \times G C F \times P C \times 1000}{(1+r)^{i}}
$$

\section{Payback Period}

The feasibility and viability of the plant may be evaluated using a simple method called the payback period $(P P)$. To put it simply, the payback period may be interpreted as the time required to gain financial return from the plant equal to the initial investment costs for the plant. Taking the initial investment costs of the plant as the initial capital cost $(C C)$, the payback period is calculated as the ratio of capital cost to net annual income obtained from the plant and given by the following equation:

$$
P P=\frac{C C}{T B S-T P C-T A X}
$$

where,

$$
\begin{gathered}
T B S=\frac{B F P \times P C}{\rho} \\
T P C=1.1 \times \frac{L C C}{n} \\
T A X=(T B S-T P C) \times T R
\end{gathered}
$$

Total Biodiesel Cost

The Annual Total Production Cost (TPC) of the biodiesel consists of the life cycle cost distributed over the life of the project of $n$ years and the reasonable profit margin. Assuming a profit margin of $10 \%$ over the distributed $L C C$, the annual total production cost (TPC) of the biodiesel may be calculated as follows:

$$
T P C=1.1 \times \frac{L C C}{n}
$$

\section{Final Biodiesel Unit Cost}

It is also important to determine the minimum sales price per unit of biodiesel fuel that would cover the costs of producing the biodiesel as well as provide the required profit margin; in this paper, this is taken to be $10 \%$. This value is equivalent to the Final Biodiesel Cost $(F B C)$ per unit, which is given by the ratio of the annual total production cost (TPC) of the biodiesel to the annual total amount of biodiesel that is produced from the plant. The Final Biodiesel Cost $(F B C)$ is given by:

$$
F B C=\frac{T P C \times \rho}{P C}
$$

\subsubsection{Potential Fuel Saving}

Biodiesel and diesel fuels have some dissimilarity in heating value or calorific value. Therefore, the biodiesel to diesel fuel substitution ratio is expressed as the following equation:

$$
S R_{w}=\frac{H V G}{H V B}
$$

The sum of the diesel fuel substitution is a function of the yearly diesel fuel consumption with a substitution ratio, which is presented by applying the equation below: 


$$
G R_{i}=\eta \times G C_{i}
$$

The total biodiesel required for replacing the diesel fuel is estimated by the diesel fuel substitution multiplied by the biodiesel to diesel fuel substitution ratio which is shown in the equation below:

$$
B C_{i}=G R_{i} \times S R_{w}
$$

The fossil diesel fuel potential energy savings can be calculated by using the following equation:

$$
T G S=\sum_{i}^{n} G R_{i} \times E C
$$

\subsubsection{Sensitivity Analysis}

The key variables such as Life Cycle Cost (LCC), Payback Period (PP), and Final Biodiesel unit Cost $(F B C)$, which form the basis of determining the feasibility/viability of the project and its economic benefits, are calculated based on key assumptions and projections. Some of the assumptions made are on the price of feedstocks $(F P)$, replacement cost $(R C)$ of the plant, operating rate $(O R)$, etc. Uncertainty in the market due to demand/supply, technologies, and other factors, may cause some of these values to vary from these key assumptions and projections, such that it may change the outcome and performance of the project.

Sensitivity analysis may be used to assess the effect of variations in key assumptions and projections, on the projected performance of the project. For the sensitivity analysis, there are several important variables that must be considered: feedstock prices, initial capital costs, operating costs, and discount rate.

The most important of these variables is the feedstock price. It is expected that the price of the feedstock will follow its market value and be sensitive to other related markets such as energy supply/demand, the market value of its substitute such as crude oil and increasing on biodiesel prices. Generally, the price of feedstock shall rise if the demand for it exceeds the supply and vice-versa. The increase in demand for the feedstocks may be caused by several factors such as an increase in demand of the biodiesel due to limited supply of crude oil, etc., with the price increase on the feedstock acting as a throttle to control biodiesel production. Similarly, the decrease in supply of the feedstock caused by, for example, natural disasters, may also increase the price of the feedstock. The feedstock used in this paper comes from Reutealis trisperma, a second generation feedstock and hence, it is comparatively price-stable as it does not need to compete with the food market unlike the first generation feedstock.

\subsubsection{Biodiesel Taxation and Subsidy Scenarios}

Policies on taxation and subsidies on a biodiesel product and its substitutes have an influence on the final cost of biodiesel in the country. Analyses are normally performed to compare the effect of different taxation and subsidy scenarios on the final price of biodiesel, to give insights to policy-maker on ways to encourage the use of biodiesel. These analyses may be based on the adoption of different policies; different tax rates, total tax exemption, and different costs of subsidy, and may also include studies on the effect of variation in the values of important input variables such as feedstock price as well as the price of its substitutes, to determine whether or not policy intervention is required to stimulate the biodiesel market.

Like other new technologies, subsidies may be inevitable for biodiesel to be on par with the fossil diesel price. The subsidy cost is usually selected based on the current subsidy cost of its substitute; namely the subsidy of diesel fuel in certain countries. 


\subsubsection{Potential Environmental Impact}

In this study, the potential environmental impact of the biodiesel plant on emissions and crop land use for biodiesel feedstocks is measured.

\section{Total Carbon Saving}

Biodiesel is comparatively cleaner when compared to fossil diesel, in terms of carbon emission. This is one of the reasons for active research in the area and the position of biodiesel as one of the possible efficient substitutes for fossil diesel. To measure the benefits of adopting biodiesel, total carbon saving (TCS) may be used; which is defined as the amount of carbon emission that may be avoided by substituting fossil diesel with biodiesel. Total carbon saving (TCS) is given by the following equation:

$$
T C S_{i}=N A E \times B C_{i}
$$

\section{Cropland Needed}

The use of feedstock for biodiesel production requires the use of cropland which could otherwise be utilized for other purposes. It is important to estimate the cropland needed (CLR) for the feedstock; calculated simply as the ratio of the feedstock needed to facilitate the fuel substitution to the feedstock yield per acre of cropland

$$
C L R=\frac{B C \times 1000}{E Y}
$$

\section{Ecosystem Carbon Payback Period}

The ecosystem carbon payback period is the period from the commencement of the project to the point in time where the overall carbon balance equals the carbon storage before the project. It may be estimated by dividing the difference between the carbons stock from converting the natural land into biodiesel feedstock cropland with the yearly carbon savings by utilizing the biodiesel fuel. Thus, the ecosystem carbon payback period $(C P P)$ may be calculated as follows:

$$
C P P=\frac{L S C-B C C}{T C S / C L R}
$$

\section{Results and Discussion}

In this study, laboratory experiments were conducted to find the physicochemical properties of Reutealis trisperma methyl ester (RTME) biodiesel. To achieve optimal conditions for esterification and transesterification processes for Reutealis trisperma oil, an ultrasonic bath stirrer method with the maximum total power of $40 \mathrm{KHz}$ was used. The esterification process was performed using $2 \%(v / v)$ sulfuric acid $\left(\mathrm{H}_{2} \mathrm{SO}_{4}\right)$, with a Methanol-to-oil molar ratio of $60 \%$ at a temperature of $55^{\circ} \mathrm{C}$ for 1 hour at $1000 \mathrm{rpm}$ stirring speed. For the transesterification process, a catalyst of $0.5 \mathrm{wt} \%$ Potassium hydroxide $(\mathrm{KOH})$ was used with a Methanol-to-oil molar ratio of $60 \%$ at a temperature of $60{ }^{\circ} \mathrm{C}$ for 1.5 hours at a stirrer speed of $1000 \mathrm{rpm}$.

The results of the laboratory experiments are tabulated in Table 1. Also tabulated are the physicochemical properties of other selected biodiesel sources; Sterculia foetida methyl ester (SFME) [44], Calophyllum inophyllum methyl ester (CIME) [61], and Ceiba pentandra methyl ester (CPME) [62], for comparison purposes. Furthermore, ASTM D6751 and EN 14214 biodiesel standard limits are also tabulated; to ensure compliance with these standards.

It is clearly demonstrated in the table that the properties of Reutealis trisperma are in agreement with the two biodiesel standard limits and hence, it can be concluded that Reutealis trisperma is a potential feedstock to be used for the production of biodiesel. 
Table 1. Physicochemical properties of Reutealis trisperma biodiesel and others biodiesel.

\begin{tabular}{cccccccc}
\hline Properties & Unit & $\begin{array}{c}\text { ASTM } \\
\text { D6751 Limit }\end{array}$ & $\begin{array}{c}\text { EN 14214 } \\
\text { Limit }\end{array}$ & RTME ${ }^{\text {a }}$ & $\begin{array}{c}\text { SFME } \\
\text { [44] }\end{array}$ & $\begin{array}{c}\text { CIME } \\
\text { [61] }\end{array}$ & $\begin{array}{c}\text { CPME } \\
\text { [62] }\end{array}$ \\
\hline Kinematic viscosity at $40^{\circ} \mathrm{C}$ & $\mathrm{mm}^{2} / \mathrm{s}$ & $1.9-6.0$ & $3.5-5.0$ & 6.48 & 3.96 & 3.45 & 4.61 \\
Density at $15^{\circ} \mathrm{C}$ & $\mathrm{kg} / \mathrm{m}^{3}$ & 880 & $860-900$ & 892 & 879.1 & 877.6 & 876.9 \\
Flash point & ${ }^{\circ} \mathrm{C}$ & Min 130 & Min 120 & 206.5 & 160.5 & 165.5 & 156.5 \\
Pour point & ${ }^{\circ} \mathrm{C}$ & -15 to 16 & - & -2 & -3.0 & 2.0 & 2.8 \\
Cloud point & ${ }^{\circ} \mathrm{C}$ & -3 to 12 & - & -1 & -3.0 & 2.0 & 3.0 \\
Calorific value & $\mathrm{MJ} / \mathrm{kg}$ & - & 35 & 40.098 & 40.427 & 41.442 & 40.493 \\
Acid value & $\mathrm{mg} \mathrm{KOH} / \mathrm{g}$ & 0.5 max & 0.5 max & 0.26 & 0.14 & 0.34 & 0.38 \\
Copper corrosion strip & - & 3 max & - & $1 \mathrm{~b}$ & - & $1 \mathrm{a}$ & 1 \\
Water content & $\% \mathrm{vol}$. & 0.05 max & $500 \mathrm{a}$ max & - & - & 0.015 & 0.045 \\
Sulfur content (S 15 grade) & $\mathrm{ppm}$ & 15 max & - & 14.85 & - & 6.23 & 13.97 \\
FAME content & $\% \mathrm{~m} / \mathrm{m}$ & - & 96.5 max & - & - & 98.7 & 98.6 \\
\hline
\end{tabular}

\subsection{Economic Indicator}

Table 2 shows the summary of the economic data indicators used in this study for a typical $50 \mathrm{kt}$ biodiesel plant in Malaysia. The lifetime of the project has been set to 20 years, which includes the first year for the construction and startup of the plant. It is assumed that the plant shall operate at $100 \%$ capacity throughout the duration of the project. Capital costs for the project are assumed to be paid through private investment and no loans are taken for the project; to make our calculations simpler, as no repayment on the loans need to be considered. The capital costs for the plant are calculated based on the required land area, equipment and instrumentations, as well as the cost for building construction. The feedstock under consideration in this paper is Reutealis trisperma oil which shall be used for the production of biodiesel oil. To operate at maximum capacity, approximately $57 \mathrm{kt}$ of crude Reutealis trisperma oil is required to produce $50 \mathrm{kt}$ of biodiesel, assuming a biodiesel conversion efficiency (CE) of $98 \%$. The selling price of biodiesel is taken to be $\$ 0.47 / \mathrm{L}$ for the first ten years and $\$ 2.00 / \mathrm{L}$ for the rest of the project lifetime.

Table 2. Summary of economic data and indicators.

\begin{tabular}{|c|c|}
\hline Input Data & Data \\
\hline Year Enacted & 2018 \\
\hline Project Lifetime $(N$, Year) & $20[63]$ \\
\hline Interest Rate $(R, \%)$ & $8.0 \%[63]$ \\
\hline Plant Capacity (t/Year) & $50,000[63]$ \\
\hline Feedstock Cost, S (\%) & $2.0 \%$ \\
\hline Feedstock Price $(\$ / t)$ & 50 \\
\hline Operating Cost/Unit (OR, $\$ / \mathrm{t} /$ Fame $)$ & 250 \\
\hline Maintenance (\% of capital cost) & $2.50 \%$ \\
\hline Yield of Biodiesel (Fame) Conversion & $87 \%$ \\
\hline Feedstock Price, Feedstock Consumption $(F P-F U, \mathrm{t})$ & 57,471 \\
\hline Depreciation Model $(D, \%)$ & $10 \%[63]$ \\
\hline Replacement Cost (\$Million) & $10,000,000[63]$ \\
\hline Glycerol Conversion Factor From Feedstock Oil $(G C F, \mathrm{~kg} / \mathrm{t})$ & 100 \\
\hline By Product Price (\$/t Glycerol) & 300 \\
\hline Glycerol Price By Product (t) & 5747.13 \\
\hline By Product Price Increase Ratio (\%) & $0 \%$ \\
\hline $\operatorname{Tax}(\%)$ & $15 \%[63]$ \\
\hline Subsidy For Biodiesel Cost (\$/L) G 1 & $0.10[63]$ \\
\hline Subsidy For Biodiesel Cost (\$/L) G 2 & $0.18[63]$ \\
\hline Diesel (Fossil) Selling Price (\$/L) & $0.58[63]$ \\
\hline Biodiesel Selling Price For First To Tenth Year (\$/L) & 0.58 \\
\hline Biodiesel Selling Price For Eleven To Till The End (\$/L) & 2 \\
\hline Density $\left(\mathrm{kg} / \mathrm{m}^{3}\right)$ & $892[64]$ \\
\hline
\end{tabular}




\subsection{Life Cycle Cost Analysis and Payback Period}

The data from Table 2 above are used to calculate the life cycle cost and payback period for biodiesel plant using Reutealis trisperma oil in Malaysia. Results of the calculations are shown in Table 3 and Figure 3. Results from the analysis indicate that the total life cycle cost of the project is approximately $\$ 710$ million, giving a unit cost of the biodiesel fuel of $\$ 0.696 / \mathrm{L}$ of biodiesel. The unit price of $\$ 0.696 / \mathrm{L}$ of biodiesel is lower than the $\$ 0.78 / \mathrm{L}$ price calculated in reference [65] for biodiesel from jatropha curcas, however, it is higher than $\$ 0.64 / \mathrm{L}$ price calculated in reference [63] for biodiesel from palm oil. It is also higher than the retail price of $\$ 0.58 / \mathrm{L}$ for fossil diesel in Malaysia. The feedstock costs from crude Reutealis trisperma oil are the biggest contributors to the life cycle cost of the project; with a percentage of around $83 \%$ of the total life cycle cost or $\$ 0.5896$ for every liter of biodiesel produced. This is followed by its operating costs; with a percentage of around $17 \%$ of the total life cycle cost or $\$ 0.13$ for every liter of biodiesel produced during the 20 years project lifetime, the sale of glycerol, by-product of the plant, contributing $\$ 16,927,840$. This is equivalent to the plant clawing back $\$ 0.0169$ for every liter of biodiesel produced. The time for the project to recoup its initial capital investment of $\$ 11,882,425$ or its payback period is 4.34 years and thus, the payback period is less than one fourth of the lifetime of the project. These results indicate the economic feasibility of the project.

Table 3. Summary of total production cost and payback period of the biodiesel production plant.

\begin{tabular}{|c|c|c|}
\hline Indicator & Life Cycle Cost (\$) & Unit Cost (\$/L of Biodiesel) \\
\hline Capital cost & $11,882,425$ & 0.0119 \\
\hline Operating cost & $122,726,843$ & 0.1227 \\
\hline Maintenance cost & $2,916,585$ & 0.0029 \\
\hline Feedstock cost & $589,522,106$ & 0.5896 \\
\hline Salvage value & 260,841 & 0.0003 \\
\hline By product credit & $16,927,840$ & 0.0169 \\
\hline Total biodiesel cost & $709,959,278$ & 0.6966 \\
\hline Payback period (year) & & 4.34 \\
\hline
\end{tabular}

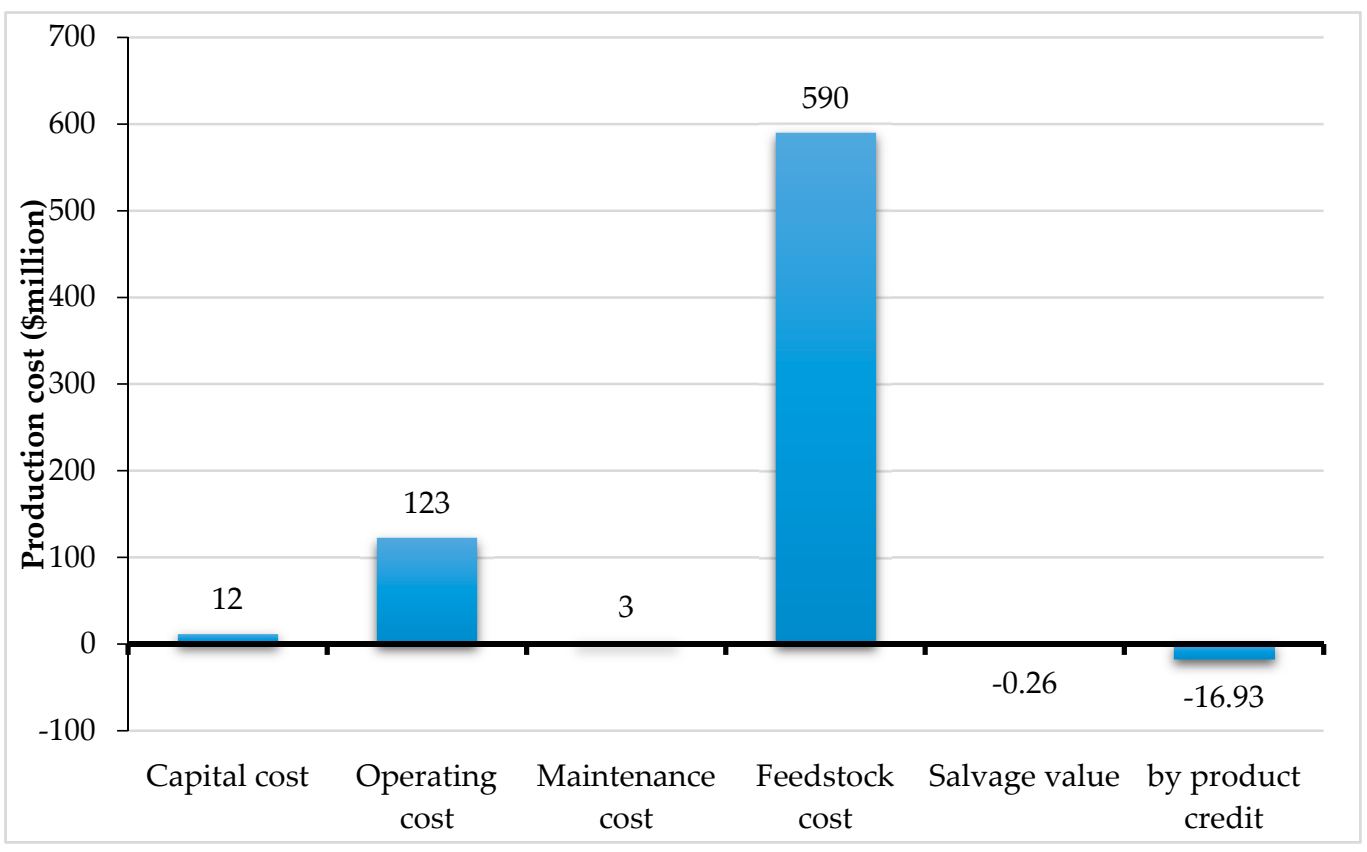

Figure 3. Distribution of Reutealis trisperma biodiesel production cost. 


\subsection{Potential Fuel Saving}

The sum of diesel fuel substitution is a function of the yearly diesel fuel consumption with a substitution ratio with biodiesel. The total biodiesel required for replacing the diesel fuel is estimated by the diesel fuel substitution multiplied by the biodiesel to diesel fuel substitution ratio. Since biodiesel and diesel fuels have some dissimilarity in heating value or calorific value, there are different amounts of biofuel required to replace fossil diesel fuel. The fossil diesel consumption and potential diesel replacement are tabulated in Table 4.

Table 4. Fossil diesel consumption and potential diesel replacement.

\begin{tabular}{ccccc}
\hline \multirow{2}{*}{ Year } & \multicolumn{2}{c}{ Diesel Consumption } & \multicolumn{2}{c}{ Diesel Replacement/Saving } \\
\cline { 2 - 5 } & (Million Liters) & (Tons) & (Million Liters) & (Tons) \\
\hline 2018 & 9907 & $8,291,846$ & 495 & 414,592 \\
2019 & 10,187 & $8,526,812$ & 509 & 425,341 \\
2020 & 10,468 & $8,761,778$ & 523 & 438,089 \\
2021 & 10,749 & $8,996,743$ & 537 & 449,837 \\
2022 & 11,030 & $9,231,709$ & 551 & 461,585 \\
2023 & 11,310 & $9,466,675$ & 566 & 473,334 \\
2024 & 11,591 & $9,701,641$ & 580 & 485,082 \\
2025 & 11,872 & $9,936,607$ & 594 & 496,830 \\
2026 & 12,152 & $10,171,573$ & 608 & 508,579 \\
2027 & 12,433 & $10,406,539$ & 622 & 520,327 \\
2028 & 12,741 & $10,641,505$ & 636 & 532,075 \\
2029 & 12,995 & $10,876,471$ & 650 & 543,824 \\
2030 & 13,275 & $11,111,437$ & 664 & 555,572 \\
2031 & 13,556 & $11,346,403$ & 678 & 567,320 \\
2032 & 13,837 & $11,581,369$ & 692 & 579,068 \\
2033 & 14,117 & $11,816,335$ & 706 & 590,817 \\
2034 & 14,398 & $12,051,301$ & 720 & 602,565 \\
2035 & 14,679 & $12,286,267$ & 734 & 614,313 \\
2036 & 14,960 & $12,521,233$ & 748 & 626,062 \\
2037 & 15,240 & $12,756,198$ & 762 & 637,810 \\
\hline
\end{tabular}

\subsection{Sensitivity Analysis}

Sensitivity analysis is performed to investigate the effect of variations on some input parameters on the life cycle cost of the project. Five (5) input variables of the model are chosen for the analysis; feedstock unit price $(F P)$, operating rate $(O R)$, initial capital cost $(C C)$, interest rate/discount rate $(r)$, and biodiesel conversion efficiency or oil conversion yield $(C E)$. The feedstock cost $(F C)$, operating cost $(O C)$, and initial capital cost $(C C)$ are three of the dominant costs associated with the LCC as identified in Equation (1) and are demonstrated in Table 3 and Figure 3; with feedstock cost and operating cost determined by the feedstock unit price $(F P)$ and operating rate $(O R)$, respectively. As present value calculations are employed, the interest rate value $(r)$ also influences the LCC of the project; a higher interest rate is expected to reduce the LCC of the project and vice versa. Finally, since the plant is assumed to produce at its maximum capacity of $50 \mathrm{kt}$ of biodiesel, the biodiesel conversion efficiency $(C E)$ dictates the amount of feedstock that should be fed into the plant to produce the required output. Figure 4 below demonstrates the effect of varying the five (5) input variables on the LCC of the biodiesel project. The left side of the figure shows the possible values of the variables; "favorable", "assumed", and "unfavorable" values on the order of appearance. For instance, the "assumed" value of the feedstock price $(\$ 980 / t)$ is the value used in the LCC calculations, giving a LCC value indicated by the mid-line on the figure. A reduction in the feedstock price to the "favorable" value ( $\$ 680 / t)$ lowers the LCC value to less than approximately $\$ 530$ million and its increase to "unfavorable" value $(\$ 1280 / t)$, increases the LCC value to approximately $\$ 890$ million. 


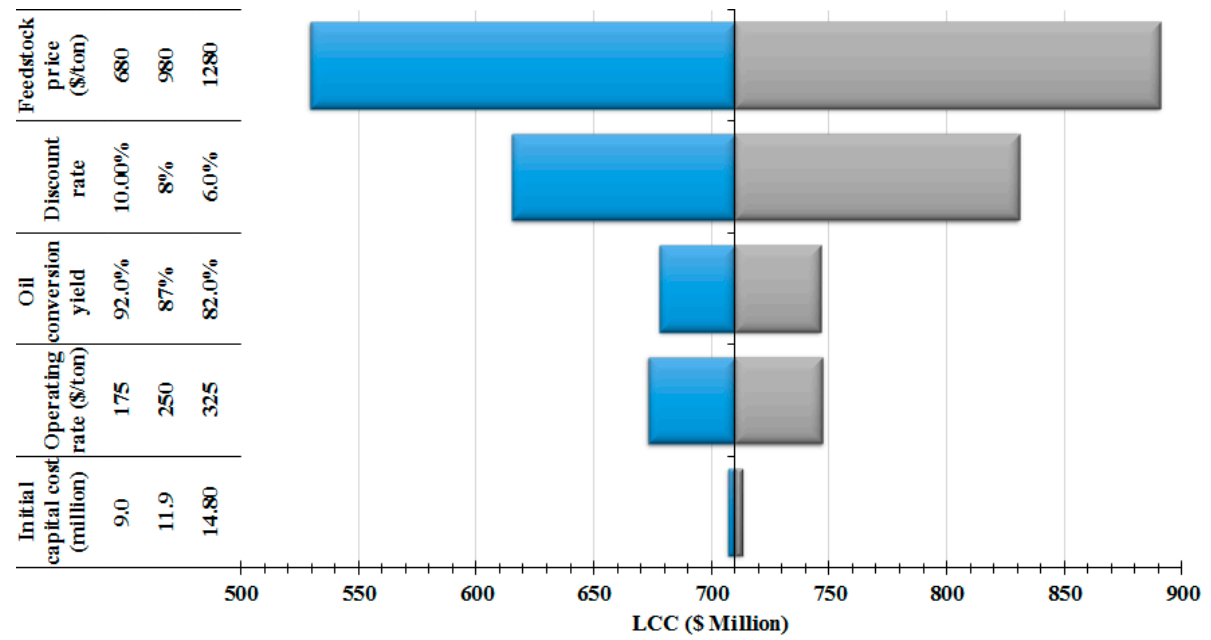

Figure 4. Sensitivity analysis of life cycle costs for Reutealis trisperma biodiesel production.

It can be seen from the figure that variations in feedstock prices have the most impact on the life cycle cost of the project; expected as the feedstock price was previously identified as the most dominant cost associated with the LCC. From the figure, a reduction in the price of Reutealis trisperma oil from $\$ 980 / \mathrm{t}$ to $\$ 680 / \mathrm{t}$ reduces the total life cycle cost from approximately $\$ 710$ million to $\$ 529$ million whilst an increase in price to $\$ 1280 / \mathrm{t}$ gives a total life cycle cost of $\$ 890$ million. This is followed by the interest rate/discount rate used in the calculation of LCC. An increase of the interest rate to $10 \%$ per annum results in a $13 \%$ reduction in total life cycle cost whilst a decrease to $6 \%$ per annum results in a $17.5 \%$ increase in the total life cycle cost. For the operating rate; defined as the operating cost per ton of biodiesel produced, decreasing the rate to $\$ 175 / \mathrm{t}$ reduces the total life cycle cost to $\$ 673$ million or a reduction of $5 \%$ from the original $L C C$. Increasing the operating rate to $\$ 325 / \mathrm{t}$ increases the total life cycle cost to $\$ 746$ million, corresponding to a $5 \%$ increase. From the figure, the $L C C$ value is least sensitive to variation in the Initial Capital Cost (CC) and is then followed by the biodiesel conversion efficiency $(C E)$; from the five input variables considered in this study. The relationship between the market price of crude Reutealis trisperma oil prices and FBC is warranted and is given in Figure 5. It can be seen that the final biodiesel unit $\operatorname{cost}(F B C)$ has a linear correlation with the price of the feedstock; an increase in the price of Reutealis trisperma oil by $\$ 0.1 / \mathrm{kg}$ results in an increase in the final biodiesel unit cost by $\$ 0.05 / \mathrm{L}$.

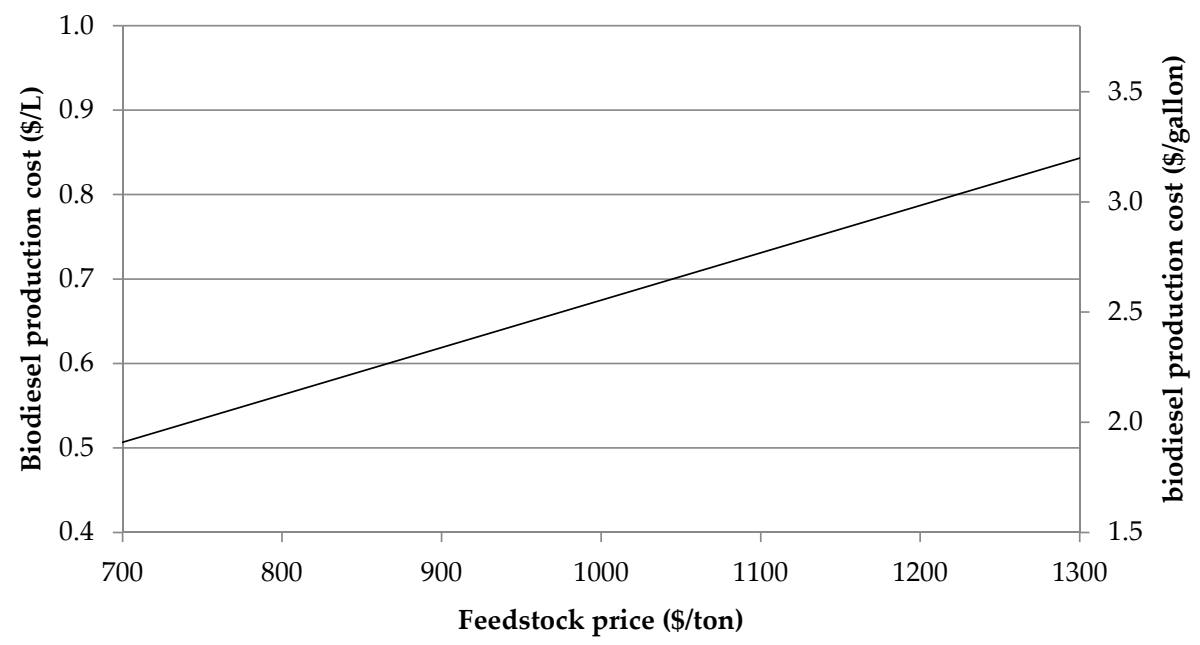

Figure 5. The impact of feedstock oil price on the biodiesel production cost. 


\subsection{Biodiesel Taxation and Subsidy Scenarios}

Taxation and subsidy levels play important roles in encouraging the adoption of biodiesel as a replacement for fossil diesel, especially as biodiesel is less attractive economically when compared to fossil diesel. Imposing a high tax rate has the effect of increasing its selling price whilst giving a subsidy that helps biodiesel to be more competitive in the market. Table 5 provides a comparison on the effect of different taxation and subsidy policies on the competitiveness of the biodiesel, obtained from Reutealis trisperma. The scenarios with total tax exemption, a tax rate of $15 \%$, and subsidy amounts of $\$ 0.10 / \mathrm{L}$ and $\$ 0.18 / \mathrm{L}$ on the biodiesel are analysed and compared with the price of fossil diesel; currently at $\$ 0.58 / \mathrm{L}$, the retail price of diesel fuel in Malaysia. It is noted that subsidy amounts of $\$ 0.10 / \mathrm{L}$ and $\$ 0.18 / \mathrm{L}$ are current subsidies given by the Malaysian government for petrol fuel and fossil diesel, respectively. The biodiesel to fossil diesel substitution ratio is taken to be 1.07. This allows for a like-for-like comparison of biodiesel and fossil diesel on the basis of energy production, instead of on the basis of volume. At a subsidy cost of $\$ 0.18 / \mathrm{L}$, the current subsidy for fossil diesel, the price of the biodiesel is actually lower than the fossil diesel. In fact, the subsidy cost at anything above $\$ 0.12 / \mathrm{L}$ makes biodiesel have a lower price than fossil diesel and hence, is more competitive. Of course, this is based on the assumptions previously made on the different costs associated with the production of biodiesel from Reutealis trisperma oil; importantly the feedstock cost of $\$ 980 / \mathrm{t}$, subsidy cost for fossil diesel at $\$ 0.18 / \mathrm{L}$, as well as the retail price of fossil diesel at $\$ 0.58 / \mathrm{L}$.

Table 5. Biodiesel taxation and subsidy level scenarios at current production costs.

\begin{tabular}{cccccc}
\hline \multirow{2}{*}{ \$/L } & \multicolumn{4}{c}{ Biodiesel } & Fossil \\
\cline { 2 - 5 } & $\begin{array}{c}\text { Total Tax } \\
\text { Exemption }\end{array}$ & $\mathbf{1 5 \% \text { of Tax }}$ & $\begin{array}{c}\text { Subsidy } \\
\mathbf{( \$ 0 . 1 0 / L )}\end{array}$ & $\begin{array}{c}\text { Subsidy } \\
\mathbf{( \$ 0 . 1 8 / L )}\end{array}$ & Diesel \\
\hline Biodiesel Cost (\$/L) & 0.697 & 0.697 & 0.697 & 0.697 & - \\
Taxes/Subsidy (\$/L) & - & 0.104 & 0.10 & 0.18 & - \\
Total (\$/L) & 0.697 & 0.801 & 0.597 & 0.517 & 0.581 \\
Total Cost (\$/L Diesel) & 0.703 & 0.808 & 0.602 & 0.521 & 0.581 \\
\hline
\end{tabular}

Naturally, the market prices of crude petroleum oil and Reutealis trisperma oil are important factors in determining whether biodiesel from Reutealis trisperma oil can actually compete with fossil diesel and if subsidies are required to encourage the use of biodiesel. Figure 6 presents the breakeven price of Reutealis trisperma oil used in the production of biodiesel at different prices of crude petroleum oil. For a given price of crude petroleum oil, Reutealis trisperma oil's prices above the line indicates that the subsidy is required for biodiesel to compete with fossil diesel whilst any prices below, indicates that no subsidy is required and savings may be expected by substituting fossil diesel with biodiesel. As an example, for the price of crude petroleum oil at $\$ 100 /$ barrel, any price above $\$ 1585 / t$ (on the line) for the Reutealis trisperma oil would require a biodiesel subsidy so that biodiesel would be able to compete with fossil diesel. Any price below $\$ 1585 / \mathrm{t}$ would make biodiesel naturally attractive and savings may be expected by using biodiesel. The opposite is also true. For a given price of crude Reutealis trisperma oil (CRTO), the CRTO price to the left of the line indicates that the subsidy for biodiesel is required to encourage the use of biodiesel over fossil diesel. Whilst the CRTO price to the right indicates that savings can potentially be obtained by substituting from fossil diesel to biodiesel. Figure 7 plots the Final Biodiesel unit Cost (FBC) as a function of feedstock price $(F P)$, with the fixed retail price of fossil diesel at $\$ 0.58 / \mathrm{L}$ and fossil diesel subsidy of $\$ 0.18 / \mathrm{L}$. It can be seen that at feedstock prices below $\$ 0.8 / \mathrm{kg}$, biodiesel can compete with fossil diesel, provided that biodiesel is tax exempted. At biodiesel subsidy levels of $\$ 0.10 / \mathrm{L}$ and $\$ 0.18 / \mathrm{L}$, biodiesel remains competitive against fossil diesel provided that the feedstock prices do not exceed $\$ 1 / \mathrm{kg}$ and $\$ 1.19 / \mathrm{kg}$, respectively. Feedstock prices over these values would see the price of biodiesel be higher than fossil diesel. 


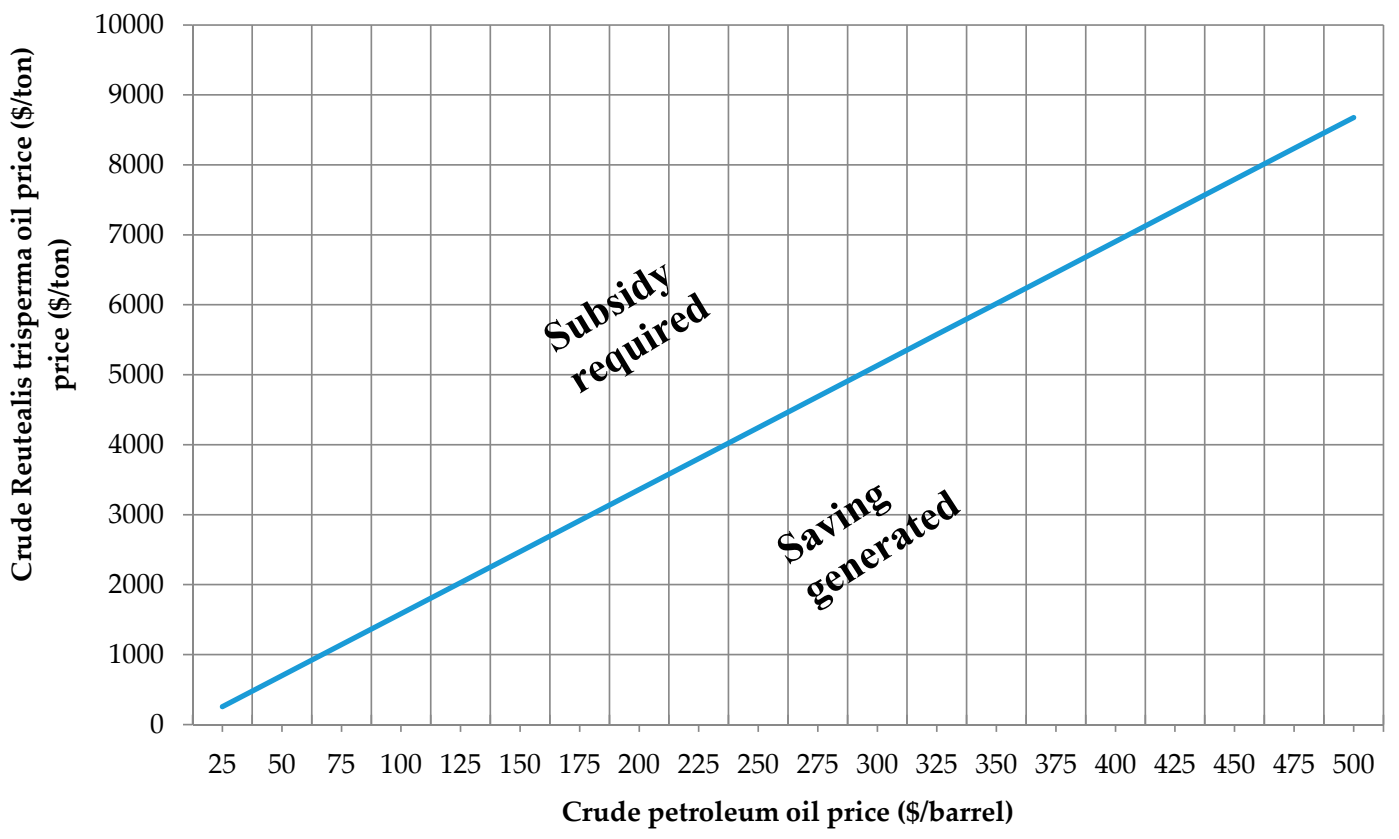

Figure 6. Breakeven price for biodiesel production at different petroleum and feedstock prices.

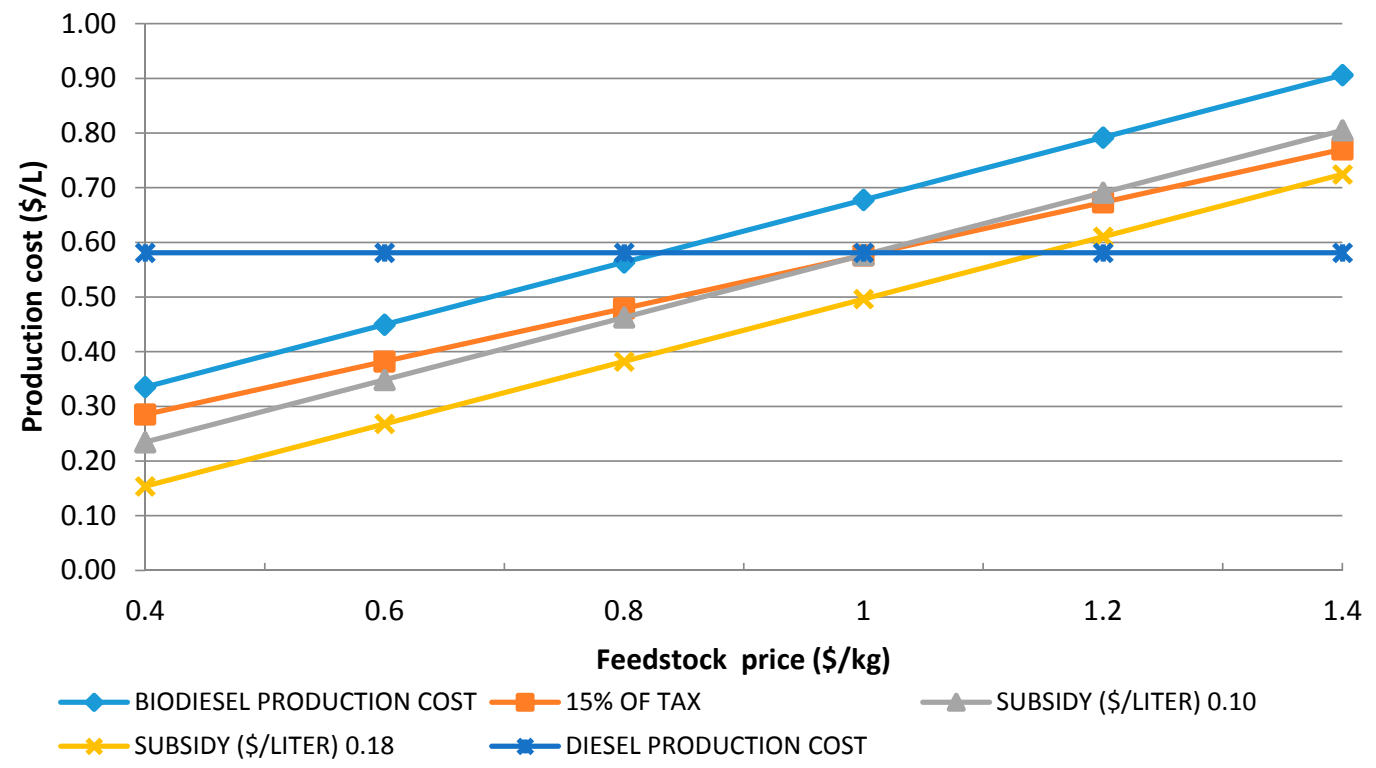

Figure 7. Taxation and subsidy scenarios of biodiesel production cost on feedstock price.

\subsection{Potential Environmental Impact}

Analysis on the potential environmental impact of adopting biodiesel includes potential emission reductions studies that may be achieved from substituting fossil diesel with biodiesel. This may simply be represented as the total energy saved $\left(T G S_{i}\right)$ from foregoing fossil diesel as well as the potential reduction in carbon emission $\left(T C S_{i}\right)$ from the substitution. Also, the estimates of the cropland required for the feedstocks $\left(C L R_{i}\right)$ is important. The results from the analysis for different replacement rates $\eta$, for a fixed assumption on fossil diesel, are given in Table 6 below. An increase in the fossil diesel replacement rate increases the amount of biodiesel required to facilitate the biodiesel to fossil diesel substitution. This increase in the requirement for biodiesel necessitates more cropland to supply the increasing feedstock. Diesel replacement rates of $1 \%, 20 \%$ and $50 \%$ require $31 \mathrm{kHa}, 626 \mathrm{kHa}$ 
and $1564 \mathrm{kHa}$ respectively. Substituting fossil diesel with biodiesel, obviously reduces fossil diesel consumption which translates into total energy saving from fossil diesel. Furthermore, as biodiesel is more environmentally friendly than fossil diesel, in terms of carbon emission, the substitutions also translates into total carbon savings.

Table 6. The results, by changing the number of replacements for the cropland required, total energy saving and total carbon saving.

\begin{tabular}{|c|c|c|c|c|c|c|}
\hline $\begin{array}{c}\text { Diesel } \\
\text { Consumption }\end{array}$ & $\begin{array}{c}\text { Diesel } \\
\text { Replacement } \\
\text { Rate }\end{array}$ & $\begin{array}{c}\text { Diesel } \\
\text { Replacement } \\
\text { Rate }\end{array}$ & $\begin{array}{l}\text { Biodiesel } \\
\text { Needed }\end{array}$ & $\begin{array}{l}\text { Cropland } \\
\text { Required }\end{array}$ & $\begin{array}{c}\text { Total Energy } \\
\text { Saving } \\
\text { (Diesel) }\end{array}$ & $\begin{array}{c}\text { Total } \\
\text { Carbon } \\
\text { Saving }\end{array}$ \\
\hline$D C$ & & $D R$ & $B C$ & CLR & TES & TCS \\
\hline $8,291,846(t)$ & $(\%)$ & (t) & (t) & (Ha) & (GJ) & (kg) \\
\hline 2018 & $1 \%$ & 82,918 & 89,126 & 31,300 & $3,573,785$ & 127,169 \\
\hline 2019 & $2 \%$ & 165,837 & 178,253 & 62,599 & $7,147,571$ & 524,338 \\
\hline 2020 & $3 \%$ & 248,755 & 267,379 & 93,899 & $10,721,356$ & 381,507 \\
\hline 2021 & $4 \%$ & 331,674 & 356,505 & 125,199 & $14,295,142$ & 508,676 \\
\hline 2022 & $5 \%$ & 414,592 & 445,631 & 156,499 & $17,868,927$ & 635,845 \\
\hline 2023 & $6 \%$ & 497,511 & 534,758 & 187,798 & $21,442,713$ & 763,014 \\
\hline 2024 & $7 \%$ & 580,492 & 623,884 & 219,098 & $25,016,498$ & 890,183 \\
\hline 2025 & $8 \%$ & 663,348 & 713,010 & 250,398 & $28,590,284$ & $1,017,352$ \\
\hline 2026 & $9 \%$ & 746,266 & 802,137 & 281,698 & $32,164,069$ & $1,144,521$ \\
\hline 2027 & $10 \%$ & 829,185 & 891,263 & 312,997 & $35,737,855$ & $1,271,691$ \\
\hline 2028 & $15 \%$ & $1,243,777$ & $1,336,894$ & 469,496 & $53,606,782$ & $1,907,536$ \\
\hline 2029 & $20 \%$ & $1,658,369$ & $1,782,526$ & 625,994 & $71,475,710$ & $2,543,381$ \\
\hline 2030 & $25 \%$ & $2,072,961$ & $2,228,157$ & 782,493 & $89,344,637$ & $3,179,226$ \\
\hline 2031 & $30 \%$ & $2,487,554$ & $2,673,788$ & 938,992 & $107,213,565$ & $3,815,072$ \\
\hline 2032 & $35 \%$ & $2,902,146$ & $3,119,420$ & $1,095,490$ & $125,082,492$ & $4,450,917$ \\
\hline 2033 & $40 \%$ & $3,316,738$ & $3,565,051$ & $1,251,989$ & $142,951,420$ & $5,086,762$ \\
\hline 2034 & $45 \%$ & $3,731,331$ & $4,010,683$ & $1,408,488$ & $160,820,347$ & $5,722,607$ \\
\hline 2035 & $50 \%$ & $4,145,923$ & $4,456,314$ & $1,564,986$ & $178,689,275$ & $6,358,453$ \\
\hline
\end{tabular}

Figure 8 illustrates the total carbon emission from fossil diesel and biodiesel for different years having different diesel replacement rates. Although total carbon emissions from both fossil diesel and biodiesel increase with an increase in the diesel replacement rate, total carbon emissions from fossil diesel is clearly higher due to its higher carbon emission factor. The difference between the carbon emissions from fossil diesel and carbon emissions from biodiesel, gives the total carbon saving (TCS) due to the diesel substitutions; from a more polluting fossil diesel onto a more efficient biodiesel. From the table, the diesel replacement rate of $1 \%$ results in total energy savings from diesel (TGS) of 3,573,785 MJ and total carbon saving (TCS) of 127,169 kg, and at the diesel replacement rate of $20 \%$, total energy savings from diesel (TGS) and total carbon saving (TCS) are 71,575,710 MJ and $2,543,381 \mathrm{~kg}$, respectively. Increasing the displacement replacement rate further has been shown to further increase the TGS and TCS values. Meanwhile, the ecosystem carbon payback period may be estimated by dividing the difference between the carbon stock from converting the natural land into biodiesel feedstock cropland with the yearly carbon savings by utilizing biodiesel fuel, as given in Equation (27). A carbon payback period (CPP) value of 25 years is obtained. 


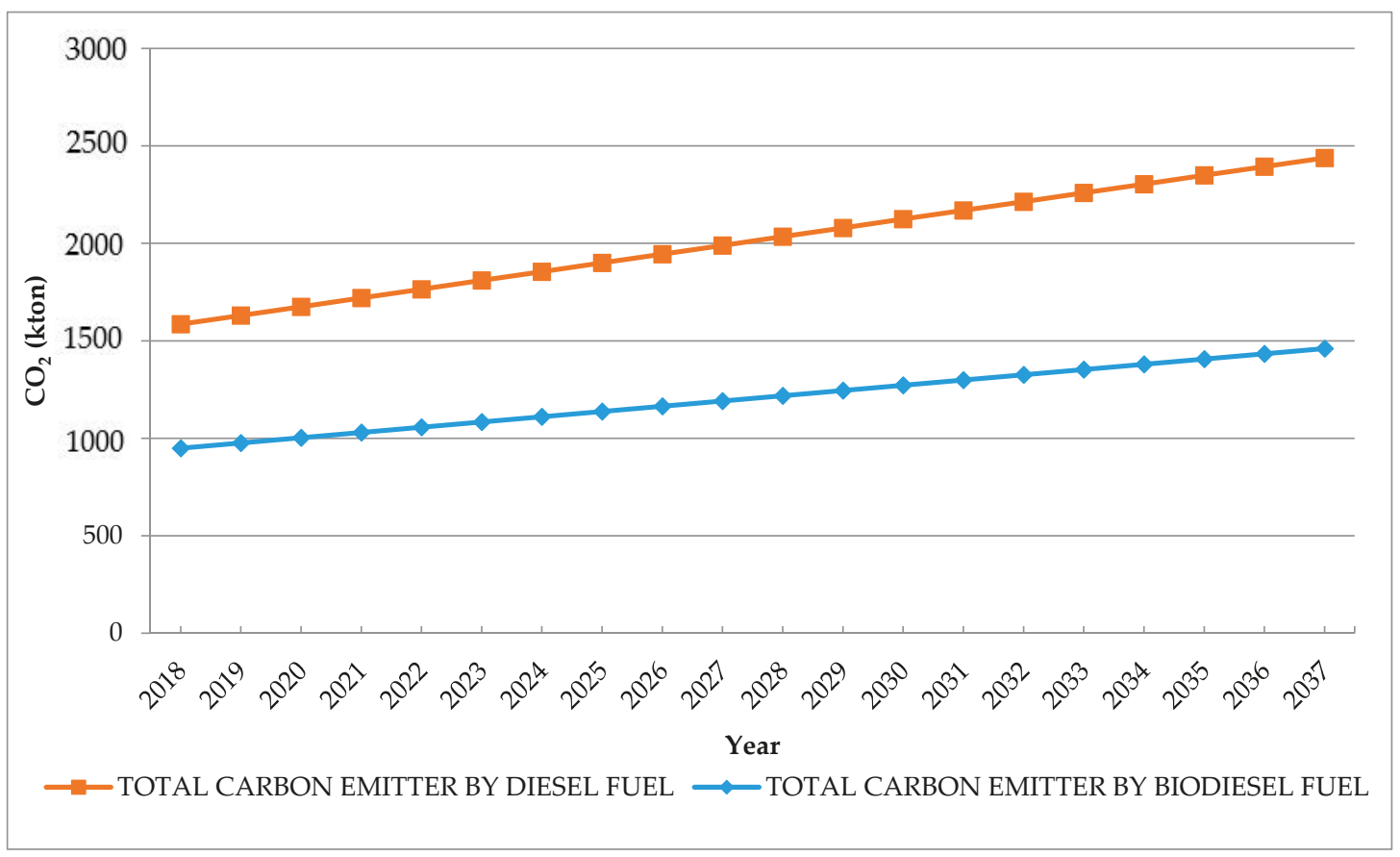

Figure 8. Comparison of total carbon emitter by diesel fuel and by biodiesel presented.

\section{Conclusions}

The techno-economic and sensitivity analyses of the Reutealis trisperma plant as a source of feedstocks for a biodiesel production plant in Malaysia have been outlined in this paper. Laboratory experiments have been performed to verify the suitability of Reutealis trisperma oil as a biodiesel feedstock. Consequently, models to calculate the feasibility of the plant based on life cycle costs, payback period, etc., as well as its sensitivity to changing input variables, have been developed for a $50 \mathrm{kt}$ biodiesel production plant with an estimated lifetime of 20 years. The life cycle costs and payback period for the biodiesel plant from crude Reutealis trisperma oil are calculated to be approximately $\$ 710$ million and 4.34 years, respectively. The total biodiesel unit cost is estimated to be $\$ 0.69 / \mathrm{L}$; competitive with fossil diesel provided the appropriate taxation and subsidy policies are put into place. Implementation and environmental impact studies have also been conducted with encouraging results. However, further studies on limiting factors and methods of overcoming them are necessary before a biodiesel production plant can be implemented in Malaysia.

Acknowledgments: The authors would like to acknowledge that this research is supported by a Fundamental Research Grant Scheme (FRGS) through the Universiti Tenaga Nasional and the Ministry of Higher Education of Malaysia (MOHE) (20160101FRGS) and the University of Malaya for the financial support under BKP Special (BKS054-2017) and Postgraduate Research Grant (PPP: PG016-2015A).

Author Contributions: Teuku Meurah Indra Riayatsyah and Hwai Chyuan Ong conceived and designed the experiments; Teuku Meurah Indra Riayatsyah performed the experiments; Teuku Meurah Indra Riayatsyah, Lisa Aditya, and Heri analyzed the data; Teuku Meurah Indra Riayatsyah wrote the paper. Hwai Chyuan Ong, Chong Wen Tong, and Teuku Meurah Indra Mahlia checked and proofread the final version of the paper.

Conflicts of Interest: The authors declare no conflict of interest.

\section{Nomenclatures}

$B C$

$B C C$

BFP

BP
Biodiesel needed $(\mathrm{t})$

Carbon stock for biodiesel cropland ( $\mathrm{t} / \mathrm{ha}$ )

Biodiesel fuel price $(\$ / \mathrm{L})$

By-product credits (\$) 


\begin{tabular}{|c|c|}
\hline$C C$ & Capital cost $(\$)$ \\
\hline$C L R$ & Cropland required (ha) \\
\hline$C P P$ & Carbon payback period (year) \\
\hline$C P W$ & Compound present worth factor $(\$)$ \\
\hline CRTO & Crude Reutealis trisperma oil \\
\hline$E C$ & Energy content of diesel fuel $(\mathrm{GJ} / \mathrm{t})$ \\
\hline EY & Ethanol yield (kg/ha) \\
\hline$F B C$ & Final biodiesel unit cost $(\$ / L)$ \\
\hline FC & Feedstock cost (\$) \\
\hline$F P$ & Feedstock price $(\$)$ \\
\hline$F U$ & Feedstock consumption $(\mathrm{t})$ \\
\hline GC & Diesel consumption $(t)$ \\
\hline GCF & Glycerol Conversion Factor $(\$)$ \\
\hline$G P$ & Glycerol Price (\$) \\
\hline$G R$ & Diesel replacement $(\mathrm{t})$ \\
\hline$H V B$ & Heating value of biodiesel fuel $(\mathrm{MJ} / \mathrm{kg})$ \\
\hline$H V G$ & Heating value of diesel fuel (MJ/kg) \\
\hline$i$ & Project year (year) \\
\hline$L C C$ & Life cycle cost $(\$)$ \\
\hline LSC & Carbon stock for natural forest ( $\mathrm{t} / \mathrm{ha}$ ) \\
\hline$M C$ & Maintenance cost (\$) \\
\hline$M R$ & Maintenance rate $(\%)$ \\
\hline$n$ & Project life time (year) \\
\hline$\eta$ & Fossil diesel replacement rate (\%) \\
\hline$O C$ & Operating cost (\$) \\
\hline$O R$ & Operating rate $(\$ / t)$ \\
\hline$P C$ & Annual Biodiesel Production Capacity ( $\mathrm{t} /$ year) \\
\hline$P P$ & Payback Period (year) \\
\hline$\rho$ & Density $\left(\mathrm{kg} / \mathrm{m}^{3}\right)$ \\
\hline$r$ & Discount rate $(\%)$ \\
\hline$R C$ & Replacement cost $(\$)$ \\
\hline$S R$ & Substitution ratio of biodiesel to diesel fuel (\%) \\
\hline$S V$ & Salvage value (\$) \\
\hline TAX & Annual total tax (\$/year) \\
\hline TBS & Annual total biodiesel sales ( $\$$ /year) \\
\hline TCS & Total carbon saving $(\mathrm{t})$ \\
\hline TPC & Annual total production cost (\$/year) \\
\hline$T R$ & Tax ratio $(\%)$ \\
\hline$\$$ & All monetary unit is in US dollar \\
\hline $\mathrm{EN}$ & European standard \\
\hline ASTM & American Society for Testing and Materials \\
\hline RTME & Reutealis trisperma methyl ester \\
\hline SFME & Sterculia foetida methyl ester \\
\hline CIME & Calophyllum inophyllum methyl ester \\
\hline CPME & Ceiba pentandra methyl ester \\
\hline FAME & Fatty acid methyl ester \\
\hline
\end{tabular}

\section{References}

1. No, S.Y. Inedible vegetable oils and their derivatives for alternative diesel fuels in ci engines: A review. Renew. Sustain. Energy Rev. 2011, 15, 131-149. [CrossRef]

2. Demirbas, A. Progress and recent trends in biodiesel fuels. Energy Convers. Manag. 2009, 50, 14-34. [CrossRef]

3. Mahlia, T.M.I.; Abdulmuin, M.Z.; Alamsyah, T.M.I.; Mukhlishien, D. An alternative energy source from palm wastes industry for malaysia and indonesia. Energy Convers. Manag. 2001, 42, 2109-2118. [CrossRef] 
4. Atabani, A.E.; Silitonga, A.S.; Badruddin, I.A.; Mahlia, T.M.I.; Masjuki, H.H.; Mekhilef, S. A comprehensive review on biodiesel as an alternative energy resource and its characteristics. Renew. Sustain. Energy Rev. 2012, 16, 2070-2093. [CrossRef]

5. Shamsuddin, A.H. Development of renewable energy in malaysia-strategic initiatives for carbon reduction in the power generation sector. Procedia Eng. 2012, 49, 384-391. [CrossRef]

6. Aditiya, H.B.; Sing, K.P.; Hanif, M.; Mahlia, T.M.I. Effect of acid pretreatment on enzymatic hydrolysis in bioethanol production from rice straw. Int. J. Technol. 2015, 6, 3-10. [CrossRef]

7. Ong, H.C.; Mahlia, T.M.I.; Masjuki, H.H.; Norhasyima, R.S. Comparison of palm oil, jatropha curcas and calophyllum inophyllum for biodiesel: A review. Renew. Sustain. Energy Rev. 2011, 15, 3501-3515. [CrossRef]

8. Giwa, S.; Abdullah, L.C.; Adam, N.M. Investigating "egusi"(citrullus colocynthis 1.) seed oil as potential biodiesel feedstock. Energies 2010, 3, 607-618. [CrossRef]

9. Murayama, T.; Fujiwara, Y.; Noto, T. Evaluating waste vegetable oils as a diesel fuel. Proc. Inst. Mech. Eng. Part. D J. Automob. Eng. 2000, 214, 141-148. [CrossRef]

10. Agarwal, A.K.; Das, L. Biodiesel development and characterization for use as a fuel in compression ignition engines. Trans.-Am. Soc. Mech. Eng. J. Eng. Gas Turb. Power 2001, 123, 440-447. [CrossRef]

11. Ong, H.C.; Masjuki, H.; Mahlia, T.; Silitonga, A.; Chong, W.; Yusaf, T. Engine performance and emissions using jatropha curcas, ceiba pentandra and calophyllum inophyllum biodiesel in a ci diesel engine. Energy 2014, 69, 427-445. [CrossRef]

12. Demirbas, A. Importance of biodiesel as transportation fuel. Energy policy 2007, 35, 4661-4670. [CrossRef]

13. Math, M.C.; Kumar, S.P.; Chetty, S.V. Technologies for biodiesel production from used cooking oil-A review. Energy Sustain. Dev. 2010, 14, 339-345. [CrossRef]

14. Karmee, S.K.; Patria, R.D.; Lin, C.S.K. Techno-economic evaluation of biodiesel production from waste cooking oil—a case study of Hong Kong. Int. J. Mol. Sci. 2015, 16, 4362-4371. [CrossRef] [PubMed]

15. Chhetri, A.B.; Watts, K.C.; Islam, M.R. Waste cooking oil as an alternate feedstock for biodiesel production. Energies 2008, 1, 3-18. [CrossRef]

16. Mata, T.M.; Martins, A.A.; Caetano, N.S. Microalgae for biodiesel production and other applications: A review. Renew. Sustain. Energy Rev. 2010, 14, 217-232. [CrossRef]

17. Ahmad, A.L.; Yasin, N.H.M.; Derek, C.J.C.; Lim, J.K. Microalgae as a sustainable energy source for biodiesel production: A review. Renew. Sustain. Energy Rev. 2011, 15, 584-593. [CrossRef]

18. Wu, X.; Ruan, R.; Du, Z.; Liu, Y. Current status and prospects of biodiesel production from microalgae. Energies 2012, 5, 2667-2682. [CrossRef]

19. Boehman, A.L. Biodiesel production and processing. Fuel Process. Technol. 2005, 86, 1057-1058. [CrossRef]

20. Keskin, A.; Gürü, M.; Altiparmak, D.; Aydin, K. Using of cotton oil soapstock biodiesel-diesel fuel blends as an alternative diesel fuel. Renew. Energy 2008, 33, 553-557. [CrossRef]

21. Ramadhas, A.S.; Jayaraj, S.; Muraleedharan, C. Use of vegetable oils as i.C. Engine fuels-A review. Renew. Energy 2004, 29, 727-742. [CrossRef]

22. Brennan, L.; Owende, P. Biofuels from microalgae-A review of technologies for production, processing, and extractions of biofuels and co-products. Renew. Sustain. Energy Rev. 2010, 14, 557-577. [CrossRef]

23. Naik, S.N.; Goud, V.V.; Rout, P.K.; Dalai, A.K. Production of first and second generation biofuels: A comprehensive review. Renew. Sustain. Energy Rev. 2010, 14, 578-597. [CrossRef]

24. Leung, D.Y.; Wu, X.; Leung, M. A review on biodiesel production using catalyzed transesterification. Appl. Energy 2010, 87, 1083-1095. [CrossRef]

25. Salahi, A.; Abbasi, M.; Mohammadi, T. Permeate flux decline during UF of oily wastewater: Experimental and modeling. Desalination 2010, 251, 153-160. [CrossRef]

26. Atadashi, I.M.; Aroua, M.K.; Abdul Aziz, A.R.; Sulaiman, N.M.N. The effects of catalysts in biodiesel production: A review. J. Ind. Eng. Chem. 2013, 19, 14-26. [CrossRef]

27. Wen, L.; Wang, Y.; Lu, D.; Hu, S.; Han, H. Preparation of KF/CaO nanocatalyst and its application in biodiesel production from Chinese tallow seed oil. Fuel 2010, 89, 2267-2271. [CrossRef]

28. Birla, A.; Singh, B.; Upadhyay, S.; Sharma, Y. Kinetics studies of synthesis of biodiesel from waste frying oil using a heterogeneous catalyst derived from snail shell. Bioresour. Technol. 2012, 106, 95-100. [CrossRef] [PubMed]

29. Dehkordi, A.M.; Ghasemi, M. Transesterification of waste cooking oil to biodiesel using ca and zr mixed oxides as heterogeneous base catalysts. Fuel Process. Technol. 2012, 97, 45-51. [CrossRef] 
30. Liu, C.; Lv, P.; Yuan, Z.; Yan, F.; Luo, W. The nanometer magnetic solid base catalyst for production of biodiesel. Renew. Energy 2010, 35, 1531-1536. [CrossRef]

31. Pukale, D.D.; Maddikeri, G.L.; Gogate, P.R.; Pandit, A.B.; Pratap, A.P. Ultrasound assisted transesterification of waste cooking oil using heterogeneous solid catalyst. Ultrason. Sonochem. 2015, 22, 278-286. [CrossRef] [PubMed]

32. Tan, Y.H.; Abdullah, M.O.; Nolasco-Hipolito, C.; Taufiq-Yap, Y.H. Waste ostrich-and chicken-eggshells as heterogeneous base catalyst for biodiesel production from used cooking oil: Catalyst characterization and biodiesel yield performance. Appl. Energy 2015, 160, 58-70. [CrossRef]

33. Torres-Rodríguez, D.A.; Romero-Ibarra, I.C.; Ibarra, I.A.; Pfeiffer, H. Biodiesel production from soybean and jatropha oils using cesium impregnated sodium zirconate as a heterogeneous base catalyst. Renew. Energy 2016, 93, 323-331. [CrossRef]

34. Ortiz-Martínez, V.; Salar-García, M.; Palacios-Nereo, F.; Olivares-Carrillo, P.; Quesada-Medina, J.; de los Ríos, A.; Hernández-Fernández, F. In-depth study of the transesterification reaction of pongamia pinnata oil for biodiesel production using catalyst-free supercritical methanol process. J. Supercrit. Fluid. 2016, 113, 23-30. [CrossRef]

35. Salar-García, M.; Ortiz-Martínez, V.; Olivares-Carrillo, P.; Quesada-Medina, J.; de los Ríos, A.; Hernández-Fernández, F. Analysis of optimal conditions for biodiesel production from jatropha oil in supercritical methanol: Quantification of thermal decomposition degree and analysis of fames. J. Supercrit. Fluid. 2016, 112, 1-6. [CrossRef]

36. Jahirul, M.I.; Koh, W.; Brown, R.J.; Senadeera, W.; O'Hara, I.; Moghaddam, L. Biodiesel production from non-edible beauty leaf (calophyllum inophyllum) oil: Process optimization using response surface methodology (rsm). Energies 2014, 7, 5317-5331. [CrossRef]

37. Devi, B.P.; Reddy, T.V.K.; Lakshmi, K.V.; Prasad, R. A green recyclable SO 3 H-carbon catalyst derived from glycerol for the production of biodiesel from FFA-containing karanja (Pongamia glabra) oil in a single step. Bioresour. Technol. 2014, 153, 370-373. [CrossRef] [PubMed]

38. Deng, X.; Han, J.; Yin, F. Net energy, $\mathrm{CO}_{2}$ emission and land-based cost-benefit analyses of jatropha biodiesel: A case study of the panzhihua region of Sichuan province in china. Energies 2012, 5, 2150-2164. [CrossRef]

39. Dharma, S.; Masjuki, H.; Ong, H.C.; Sebayang, A.; Silitonga, A.; Kusumo, F.; Mahlia, T. Optimization of biodiesel production process for mixed jatropha curcas-ceiba pentandra biodiesel using response surface methodology. Energy Convers. Manag. 2016, 115, 178-190. [CrossRef]

40. Mumtaz, M.W.; Mukhtar, H.; Dilawer, U.A.; Hussain, S.M.; Hussain, M.; Iqbal, M.; Adnan, A.; Nisar, J. Biocatalytic transesterification of eruca sativa oil for the production of biodiesel. Biocatal. Agric. Biotechnol. 2016, 5, 162-167. [CrossRef]

41. Silitonga, A.; Masjuki, H.; Ong, H.C.; Yusaf, T.; Kusumo, F.; Mahlia, T. Synthesis and optimization of hevea brasiliensis and ricinus communis as feedstock for biodiesel production: A comparative study. Ind. Crops Prod. 2016, 85, 274-286. [CrossRef]

42. Thiruvengadaravi, K.; Nandagopal, J.; Baskaralingam, P.; Bala, V.S.S.; Sivanesan, S. Acid-catalyzed esterification of karanja (Pongamia pinnata) oil with high free fatty acids for biodiesel production. Fuel 2012, 98, 1-4. [CrossRef]

43. Jahirul, M.I.; Brown, R.J.; Senadeera, W.; O’Hara, I.M.; Ristovski, Z.D. The use of artificial neural networks for identifying sustainable biodiesel feedstocks. Energies 2013, 6, 3764-3806. [CrossRef]

44. Silitonga, A.; Ong, H.; Masjuki, H.; Mahlia, T.; Chong, W.; Yusaf, T.F. Production of biodiesel from sterculia foetida and its process optimization. Fuel 2013, 111, 478-484. [CrossRef]

45. Achten, W.M.; Sharma, N.; Muys, B.; Mathijs, E.; Vantomme, P. Opportunities and constraints of promoting new tree crops-Lessons learned from jatropha. Sustainability 2014, 6, 3213-3231. [CrossRef]

46. Dhingra, S.; Bhushan, G.; Dubey, K.K. Performance and emission parameters optimization of mahua (Madhuca indica) based biodiesel in direct injection diesel engine using response surface methodology. J. Renew. Sustain. Energy 2013, 5, 063117. [CrossRef]

47. Chen, Y.-H.; Tang, T.-C.; Chiang, T.-H.; Huang, B.-Y.; Chang, C.-Y.; Chiang, P.-C.; Shie, J.-L.; Franzreb, M.; Chen, L.-Y. A complementary biodiesel blend from soapnut oil and free fatty acids. Energies 2012, 5, 3137-3148. [CrossRef]

48. Chhetri, A.B.; Tango, M.S.; Budge, S.M.; Watts, K.C.; Islam, M.R. Non-edible plant oils as new sources for biodiesel production. Int. J. Mol. Sci. 2008, 9, 169-180. [CrossRef] [PubMed] 
49. Phoo, Z.W.M.M.; Razon, L.F.; Knothe, G.; Ilham, Z.; Goembira, F.; Madrazo, C.F.; Roces, S.A.; Saka, S. Evaluation of indian milkweed (calotropis gigantea) seed oil as alternative feedstock for biodiesel. Ind. Crops Prod. 2014, 54, 226-232. [CrossRef]

50. Yerranguntla, R.; Zubaidha, P.; Jakku, N.; Kondhare, D.; Deshmukh, S.; Saiprakash, S. Production of biodiesel from guizotia abyssinica seed oil using crystalline manganese carbonate $\left(\mathrm{MnCO}_{3}\right)$ a green catalyst. Catal. Sustain. Energy 2012, 1, 22-27. [CrossRef]

51. Chen, Y.-H.; Chang, C.-C.; Chang, M.-C.; Chang, C.-Y. Biodiesel production from tung oil and blended oil via ultrasonic transesterification process. J. Taiwan Inst. Chem. Eng. 2011, 42, 640-644.

52. Qin, S.; Sun, Y.; Shi, C.; He, L.; Meng, Y.; Ren, X. Deacidification of pistacia chinensis oil as a promising non-edible feedstock for biodiesel production in china. Energies 2012, 5, 2759-2770. [CrossRef]

53. Holilah, H.; Prasetyoko, D.; Oetami, T.P.; Santosa, E.B.; Zein, Y.M.; Bahruji, H.; Fansuri, H.; Ediati, R.; Juwari, J. The potential of reutealis trisperma seed as a new non-edible source for biodiesel production. Biomass Convers. Biorefinery 2015, 5, 347-353. [CrossRef]

54. Kansedo, J.; Lee, K.T.; Bhatia, S. Cerbera odollam (sea mango) oil as a promising non-edible feedstock for biodiesel production. Fuel 2009, 88, 1148-1150. [CrossRef]

55. Discover, L. Reutealis Trisperma (Blanco) Airy Shaw. Available online: http://www.discoverlife.org/mp/ 20m?kind=Reutealis+trisperma (accessed on 20 March 2016).

56. IUCN. Reutealis Trisperma. Available online: http://www.iucnredlist.org/details/33898/0 (accessed on 23 February 2016).

57. Natakarmana, H. Kemiri Sunan (Aleurites Trisperma). Available online: http://sunan-drajat.blogspot.my/ (accessed on 13 April 2016).

58. Van der Vossen, H.A.M.; Umali, B.E. Plant Resources of South-East Asia; No. 14; Backhuys: Leiden, The Netherlands, 2001.

59. Howell, S. Time to take the biodiesel plunge? Render Mag. 2005, 10-14.

60. Pagliaro, M.; Ciriminna, R.; Kimura, H.; Rossi, M.; Della Pina, C. From glycerol to value-added products. Angew. Chem. Int. Ed. 2007, 46, 4434-4440. [CrossRef] [PubMed]

61. Ong, H.C.; Masjuki, H.; Mahlia, T.; Silitonga, A.; Chong, W.; Leong, K. Optimization of biodiesel production and engine performance from high free fatty acid calophyllum inophyllum oil in ci diesel engine. Energy Convers. Manag. 2014, 81, 30-40. [CrossRef]

62. Silitonga, A.; Ong, H.; Mahlia, T.; Masjuki, H.; Chong, W. Characterization and production of ceiba pentandra biodiesel and its blends. Fuel 2013, 108, 855-858. [CrossRef]

63. Ong, H.; Mahlia, T.; Masjuki, H.; Honnery, D. Life cycle cost and sensitivity analysis of palm biodiesel production. Fuel 2012, 98, 131-139. [CrossRef]

64. Riayatsyah, T.M.I. Techno-Economics Analysis of Biodiesel Production from Non-Edible Reutealis Trisperma Oil. Master's Thesis, Department of Mechanical Engineering, University of Malaya, Kuala Lumpur, Malaysia, 2017.

65. Yusuf, N.; Kamarudin, S.K. Techno-economic analysis of biodiesel production from Jatropha curcas via a supercritical methanol process. Energy Convers. Manag. 2013, 75, 710-717. [CrossRef]

(C) 2017 by the authors. Licensee MDPI, Basel, Switzerland. This article is an open access article distributed under the terms and conditions of the Creative Commons Attribution (CC BY) license (http://creativecommons.org/licenses/by/4.0/). 